\title{
ANALISIS PEMANFAATAN RUANG WILAYAH PESISIR KABUPATEN PANDEGLANG, PROVINSI BANTEN
}

\section{Analysis of Coastal Areas Utilization in Pandeglang District, Banten Province}

\author{
Siti Maesaroh'), Baba Barus'"), dan Laode Syamsul Iman²) \\ 1) Alumni Departemen Ilmu Tanah dan Sumberdaya Lahan, Fakultas Pertanian IPB, J1. Meranti Kampus IPB \\ Darmaga Bogor 16680 \\ 2) Departemen Ilmu Tanah dan Sumberdaya Lahan, Fakultas Pertanian IPB, J1. Meranti Kampus IPB Darmaga \\ Bogor 16680
}

\begin{abstract}
The Pandeglang regency coastal areas are characterised by many economic acitivities and contain high potential for development with various problems. This study aims to identify problems and to analyze factors that have dominant effect on the utilization of coastal areas, and to analize spatially the coastal area and to find the spatial suitability for fisheries, aquaculture, marine tourism, fishing harbors and marine conservation. Analysis are conducted through questionnaires to the experts to find criteria that influence the Analytic Network Process (ANP) and spatial analysis using overlay technique. The weights of criteria and parameters have mutual influence in policy cluster function, ecological and socio-economy. The influential criteria is RZWP3K (provincial spatial planning), RTRW (district spatial planning), transportation, population structure, infrastructure, physical suitability, land use and risk of hazard. The locations suitable for marine aquaculture are Pagelaran to Panimbang subdistrict offshore area. Conservation activity is suitable for Taman Jaya coastal water around the island of Badul. Areas that suitable for marine tourism are Sukaresmi to Tanjung Jaya and the small islands at the Ujung Kulon. Fishing port is suitable built in the village of Caringin, Cigondang, Pejamben and Teluk. The most suitable areas for fisheries activity are Subdistrict of Labuan, Panimbang and Sukaresmi.
\end{abstract}

Keywords: Analytic Network Process (ANP), coastal area, Pandeglang district, spatial analysis, spatial utilization

\begin{abstract}
ABSTRAK
Wilayah pantai Kabupaten Pandeglang saat ini dipenuhi oleh aktivitas ekonomi dan mempunyai potensi pengembangan dengan berbagai problem. Studi ini bertujuan untuk mengidentifikasi problem dan menganalisis faktor dominan yang mempengaruhi pemanfaatannya serta kesesuaiannya secara ruang untuk perikanan, budidaya perikanan, pariwisata marin, pelabuhan perikanan, dan konservasi laut. Analisis dilakukan dengan pencarian kriteria melalui pendapat ahli melalui metode Proses Analisis Jaringan (ANP - Analytic Network Process) dan analisis spasial tumpang-tindih. Pembobotan kriteria dan parameter mempunyai pengaruh bersama dalam pengelompokan fungsi kebijakan, ekologi dan sosialekonomi. Kriteria yang berperan adalah perencanaan ruang provinsi (RTRWP) dan kabupaten (RTRWK), transportasi, struktur populasi, infrastruktur, kesesuaian fisik, penggunaan lahan dan risiko ancaman bahaya. Lokasi yang sesuai untuk budidaya perikanan laut adalah wilayah pantai kecamatan Pagelaran hingga Panimbang. Daerah konservasi terletak di perairan Taman Jaya di sekitar pulau Badul. Wilayah yang sesuai untuk daerah pariwisata adalah Sukaresmi ke Tanjung Jaya serta pulau-pulau kecil di Ujung Kulon. Pelabuhan perikanan sesuai dibangun di kampung Caringin, Cigondong, Pejamben dan Teluk. Daerah paling sesuai untuk aktivitas perikanan di Kecamatan Labuan, Panimbang dan Sukaresmi.
\end{abstract}

Kata kunci: Proses analisis jaringan, daerah pesisir, kabupaten Pandeglang, analisis spasial, pemanfaatan ruang

\section{PENDAHULUAN}

Penataan ruang merupakan upaya untuk mengatur segala aktivitas dan kegiatan manusia dalam hubungannya dengan keseimbangan ekosistem mencakup penggunaan lahan dan sumberdaya alam agar bisa terkendali dan berkelanjutan sesuai dengan tujuan pembangunan. Menurut Undang-Undang No. 27 tahun 2007 tentang pengelolaan wilayah pesisir, ruang lingkup pengaturan wilayah pesisir dan pulau-pulau kecil meliputi daerah peralihan antara ekosistem darat dan laut yang dipengaruhi oleh perubahan di darat dan laut, serta cakupannya ke arah darat mencakup wilayah administrasi kecamatan dan ke arah laut sejauh 12 mil diukur dari garis pantai merupakan kewenangan provinsi sedangkan kewenangan Kabupaten sepertiganya dari kewenangan tersebut.

Kabupaten Pandeglang memiliki wilayah daratan seluas $2,746.89 \mathrm{~km}^{2}$ dan perairan laut seluas $1,702 \mathrm{~km}^{2}$ dan garis pantai $230 \mathrm{~km}$ yang mempunyai potensi alam yang beraneka ragam dan telah berkembang menjadi aset daerah 
dengan berbagai pemanfaatan (Dahuri et al. 2001). Tingginya aktivitas manusia yang terjadi pada wilayah pesisir Kabupaten Pandeglang berupa aktivitas pariwisata, pertanian, perikanan tangkap dan budidaya, pelabuhan perikanan pantai dan lain-lain sudah ada yang menimbulkan dampak negatif.

Dampak negatif aktivitas tersebut menyebabkan berbagai permasalahan seperti:(1) Pencemaran bahan organik sepanjang pesisir pantai; (2) Kegiatan pariwisata yang tak terkendali, (3) Alih fungsi lahan mangrove (4) Terdegradasinya garis pantai, (5) Sedimentasi di muara sungai (6) Tingginya kekeruhan sepanjang perairan laut (Dirjen KP3K, 2011) dan (7) Tekanan pencemaran.

Untuk mengatasi permasalahan tersebut dibutuhkan strategi penataan ruang yang bertujuan untuk mengurangi dampak lingkungan yang ditimbulkannya. Hingga saat ini pengaturan pemanfaatan ruang ini belum didukung dengan peraturan tata ruang, baik untuk kabupaten maupun untuk daerah pesisirnya. Dalam Undang-Undang No. 27 tahun 2007 tentang Pengelolaan Wilayah Pesisir dan Pulau-pulau Kecil tercantum penataan ruang wilayah laut berbasis zonasi yaitu bentuk konsep perencanaan dengan rekayasa teknik pemanfaatan ruang melalui penetapan batas-batas fungsional sesuai dengan potensi sumberdaya dan daya dukung serta proses-proses ekologis yang berlangsung dalam satu kesatuan dalam ekosistem pesisir (Sekretariat Kabinet, 2007a,b). Menurut Pourebrahim et al. (2010) Analytic Network Process (ANP) merupakan metode dari analisis multikriteria yang mengintegrasikan, menganalisis dan menggambarkan informasi yang terdapat dalam wilayah pesisir untuk menemukan kriteria yang mempunyai peranan paling besar pengaruhnya dengan mempertimbangkan pendapat dan pengetahuan dari para ahli yang berkompeten di bidang wilayah pesisir ini. Metode ANP ini merupakan pengembangan konsep integrasi data yang tidak linier (Buyukyacizi dan Meral, 2003), dan dapat membentuk jaringan. Metode ini merupakan pengembangan dari konsep Analytic Hierarchy Process, yang berhasil mengakomodasi keterkaitan antar kriteria dan alternatif, yang bersifat linier (Saaty, 2005).

Tujuan penelitian ini adalah: (1). Mengidentifikasi masalah pemanfaatan ruang di wilayah pesisir; (2) Menganalisis faktor yang berpengaruh penting dalam pemanfaatan ruang wilayah pesisir; (3) Menganalisis kesesuaian lahan dan penyusunan peta arah pemanfaatan ruang untuk kawasan perikanan tangkap, budidaya laut, pariwisata bahari, pelabuhan perikanan serta konservasi perairan; dan (4) Menyusun arahan pemanfaatan ruang wilayah pesisir Kabupaten Pandeglang berdasarkan fungsi ekologi, sosial ekonomi dan kebijakan. Manfaat yang diharapkan dapat dijadikan sebagai salah satu bahan pertimbangan bagi pengambilan keputusan penentuan kebijakan bagi pemerintah daerah dalam pemanfaatan ruang dan penetapan kawasan pengelolaan wilayah pesisir secara terpadu di Kabupaten Pandeglang.

\section{BAHAN DAN METODE}

Penelitian dilaksanakan pada bulan Juli-Oktober 2012, di pesisir Kabupaten Pandeglang. Jenis data terdiri atas : (1) data primer dengan observasi, wawancara dan kuesioner serta survei lapang. (2). Data sekunder diperoleh dari literatur terkait, data dan informasi dari instansi pemerintah berupa : peta RTRW 2011(Pemda Kab Pandeglang, 2011), Peta RBI Bakosurtanal skala 1:25,000, peta bathymetri skala 1:200,000) (Dishidros, 2012), peta lereng skala 1:25,000 (pemda), peta kepadatan penduduk skala 1:25,000 (pemda), data potensi desa tahun 2012, data sebaran terumbu karang dari instansi Dinas Kelautan dan Perikanan, Pandeglang dalam Angka tahun 2008-2011, data kualitas perairan dari www.erddap.com.

Alat yang digunakan adalah kamera dijital dan seperangkat komputer yang dilengkapi Sistem Informasi Geografis, Superdecision, perangkat interpolasi Surfer dan Microsoft Excel.

Penelitian dibagi atas empat tahapan yaitu :

\section{Tahap 1. Mengidentifikasi dan Mengevaluasi Pemanfaaatan Ruang Pesisir}

Tahap ini dilakukan dengan mewawancarai 12 responden yang yang paham permasalahan perikanan dan kelautan dengan sebanyak dua kali, dari pihak Bappeda, Dinas Kelautan dan Perikanan Provinsi Banten dan Kabupaten Pandeglang, Tata ruang dan Pertamanan, Kab Pandeglang, Akademisi dari Universitas Tirtayasa, dan Tokoh Masyarakat. Wawancara pertama untuk menjabarkan segala isu dan permasalahan terkait pemanfaatan ruang. Wawancara kedua untuk memberi bobot penilaian menggunakan matriks perbandingan berpasangan.

\section{Tahap 2. Penentuan Tingkat Pengaruh Kriteria dengan ANP}

Tahapan ini dilakukan dengan teknik ANP dengan disain kriteria sebagai berikut: (1). Penyusunan struktur jaringan; (2). Pembobotan para ahli; (3). Consistency Ratio (CR); (4). Bobot rataan geometrik; dan (5). Matriks prioritas.

\section{Tahap 3. Analisis Spasial}

Analisis spasial dilakukan dengan metode tumpang susun (overlay) terhadap parameter yang berbentuk poligon. Proses overlay dilakukan dengan cara intersect masing-masing lapisan tiap jenis kesesuaian pemanfaatan ruang.

\section{Tahap 4. Analisis Kesesuaian}

Kegiatan yang dilakukan adalah:

1. Penetapan persyaratan (parameter dan kriteria) mengikuti kriteria yang sudah ada seperti kriteria fisik di darat dan laut (Dirjen KP3K, 2011; Rumagia, 2008) untuk menentukan kesesuaian suatu pemanfaatan ruang

2. Standarisasi, pembobotan dan pemberian skor subkriteria. Penilaian secara kuantitatif terhadap tingkat subkriteria lahan.

3. Perhitungan nilai suatu kriteria Analisis dilakukan secara kuantitatif dengan rumus sebagai berikut: 
dimana :

$$
\mathrm{Y}=\sum \text { ai. } \mathrm{X}_{\mathrm{n}}
$$

$\mathrm{Y} \quad=$ Nilai akhir suatu subkriteria

ai $=$ Nilai pembobot kriteria ke-i yang telah distandarisasi dari ANP
$\mathrm{X}_{\mathrm{n}} \quad=$ Skor pada pemanfaatan ruang $(\mathrm{n}=1,2$ dan 3$)$

Tabel 1 merupakan contoh proses penghitungan nilai akhir untuk menentukan nilai kesesuaian lahan pemanfaatan ruang tertentu.

Tabel 1. Contoh perhitungan nilai kesesuaian lahan pemanfaatan ruang tertentu

\begin{tabular}{|c|c|c|c|c|c|}
\hline $\begin{array}{c}\text { Kriteria } \\
\text { Kesesuaian lahan } \\
\end{array}$ & Subkriteria & $\begin{array}{c}\text { Skor } \\
\left(\mathbf{X}_{n}\right)\end{array}$ & $\begin{array}{c}\text { Bobot } \\
\text { ANP (D) } \\
\end{array}$ & $\begin{array}{c}\text { Standarisasi } \\
\text { (ai) }\end{array}$ & $\begin{array}{c}\text { Nilai Bobot Akhir } \\
(\mathrm{Y})\end{array}$ \\
\hline \multirow[t]{3}{*}{ Kedalaman perairan } & $8-10 \mathrm{~m}$ & 3 & \multirow{3}{*}{ A } & \multirow{3}{*}{$\mathrm{A} / \mathrm{D}$} & $\mathrm{X}_{3}{ }^{*}(\mathrm{~A} / \mathrm{D})$ \\
\hline & 4-7 $\mathrm{m}$ dan $10-15 \mathrm{~m}$ & 2 & & & $\mathrm{X}_{2} *(\mathrm{~A} / \mathrm{D})$ \\
\hline & $<4 \mathrm{~m}$ dan $>10 \mathrm{~m}$ & 1 & & & $\mathrm{X}_{1} *(\mathrm{~A} / \mathrm{D})$ \\
\hline \multirow[t]{3}{*}{ Transportasi } & Banyak & 3 & \multirow{3}{*}{ B } & \multirow{3}{*}{$\mathrm{B} / \mathrm{D}$} & $\mathrm{X}_{3} *(\mathrm{~B} / \mathrm{D})$ \\
\hline & Jarang & 2 & & & $\mathrm{X}_{2} *(\mathrm{~B} / \mathrm{D})$ \\
\hline & Tidak ada & 1 & & & $\mathrm{X}_{1} *(\mathrm{~B} / \mathrm{D})$ \\
\hline \multirow[t]{3}{*}{ RTRW } & Perkotaan & 3 & \multirow{3}{*}{$\mathrm{C}$} & \multirow{3}{*}{$\mathrm{C} / \mathrm{D}$} & $\mathrm{X}_{3} *(\mathrm{C} / \mathrm{D})$ \\
\hline & Sawah, perkebunan & 2 & & & $\mathrm{X}_{2} *(\mathrm{C} / \mathrm{D})$ \\
\hline & Hutan lindung & 1 & & & $\mathrm{X}_{1} *(\mathrm{C} / \mathrm{D})$ \\
\hline Jumlah & & & $\mathrm{D}=$ & 1.00 & \\
\hline
\end{tabular}

\section{Pembagian kelas lahan}

Setelah mendapat nilai bobot akhir kesesuaian untuk pemanfaatan budidaya laut, kawasan konservasi perairan, kawasan pariwisata bahari, kawasan pelabuhan perikanan pantai dan kawasan perikanan tangkap, analisis dilanjutkan dengan membagi kelas lahan berdasarkan kriteria sesuai, kurang sesuai dan tidak sesuai. Pembagian kelas lahan didahului dengan mencari nilai selang kelas dengan rumus:

$$
\mathrm{SK}=\frac{\sum Y \max -\sum Y \min }{\sum \text { kelas }}
$$

dimana :

SK $=$ Nilai selang kelas

$\sum \mathrm{Ymax} \quad=$ Jumlah total nilai maksimum

kesesuaian lahan

$\sum$ Ymin $=$ Jumlah total nilai minimum kesesuaian

$\sum$ kelas

lahan

$=3$

5. Membandingkan nilai lahan dengan nilai masingmasing kelas lahan;

6. Menyajikan secara grafis berupa peta arahan pemanfaatan ruang.

\section{Tahap 5. Sintesis Pemanfaatan Ruang}

Sintesis merupakan tahap terakhir dalam menentukan pemanfaatan ruang wilayah pesisir dengan teknik tumpang-tindih semua peta kawasan yang telah dievaluasi kesesuaiannya. Pendekatan ini sudah biasa dilakukan secara spasial dengan SIG (Elly, 2006; Mulyawati, 2008). Proses penentuan suatu daerah ditentukan pemanfaatan ruangnya dengan melihat rataan bobot tertinggi setiap selang kelas yang dihasilkan pada lima kawasan kesesuaian pemanfaatan ruang. Nilai tertinggi akan dipakai sebagai landasan pertama untuk penentuan keputusan rencana pemanfaatan ruang. Selanjutnya, dibuat matriks keterkaitan antar kawasan pemanfaatan ruang dengan menguraikan hubungannya untuk melihat harmonisasi antar pemanfaatan ruang. Matriks ini berisi susunan aktifitas: budidaya laut, konservasi perairan, pariwisata, pelabuhan dan perikanan tangkap dan berfungsi untuk menjelaskan susunan aktifitas yang dapat diterapkan dalam masing-masing peruntukan wilayah (Tabel 2).

\begin{tabular}{|c|c|c|c|c|c|c|}
\hline & Budidaya laut & Budidaya laut & & & & \\
\hline & \begin{tabular}{|l|} 
Konservasi perairan \\
\end{tabular} & 4 & Konservasi perairan & & & \\
\hline & \begin{tabular}{|l} 
Pariwisata bahari \\
\end{tabular} & 1 & $\square$ & Pariwisata bahari & & \\
\hline & Pelabuhan perikanan & $\Delta$ & $\boldsymbol{\Delta}$ & $\boldsymbol{\Delta}$ & $\begin{array}{c}\text { Pelabuhan } \\
\text { perikanan }\end{array}$ & \\
\hline & Perikanan tangkap & $\circ$ & 】 & 4 & $\square$ & $\begin{array}{l}\text { Perikanan } \\
\text { tangkap }\end{array}$ \\
\hline
\end{tabular}

Tabel 2. Matriks keterkaitan pemanfaatan ruang pesisir untuk pengambilan keputusan alokasi ruang 
Tabel 2 dipakai untuk memandu jika dilakukan pengambilan keputusan ruang, dan adanya beberapa pilihan penggunaan. Misalnya nilai kesesuaian menunjukan kesesuaian untuk budidaya laut tetapi konflik dengan pelabuhan perikanan, maka harus dipertimbangkan jika lokasi dan pengelolaannya tidak diatur maka budidaya dapat terganggu. Jika ditemukan nilainya sama tinggi atau dianggap keduanya sesuai dan tidak bertentangan, maka kedua pilihan ini tetap ditampilkan.

\section{HASIL DAN PEMBAHASAN}

\section{Metode Analytic Network Process untuk Seleksi Kriteria}

\section{Identifikasi Parameter yang Berpengaruh}

Berdasarkan pengolahan data lapang dan hasil wawancara dengan berbagai pihak, maka ditemukan berbagai permasalahan di wilayah studi yang ditandai dengan adanya tumpang tindihnya kewenangan antar instansi, yang bersumber dari konflik kepentingan. Selain itu, berdasarkan informasi Dinas Kelautan dan Perikanan, saat ini belum ada perencanaan terarah untuk pengelolaan wilayah pesisir secara terpadu yang tercermin dari semua instansi berprioritas untuk memenuhi target penghasilan daerah. Pada saat bersamaan, banyak stakeholder yang memanfaatkan ruang dengan tidak memperhatikan kelestarian sumberdaya alam, sehingga terjadi degradasi lingkungan.

Data analisis menunjukkan parameter penting fungsi ekologi adalah kesesuaian fisik perairan, kualitas perairan, penggunaan lahan, area bernilai tinggi, kedekatan dengan sumber pencemar, resiko bahaya dan pengaruh iklim global. Pada fungsi sosial ekonomi, parameter penting adalah kedekatan dengan sarana-prasarana penting, aksessibilitas, sarana-prasarana perikanan, struktur populasi penduduk dan tekanan penduduk. Paramerer penting fungsi kebijakan adalah rencana zonasi wilayah pesisir provinsi dan rencana tata ruang wilayah kabupaten.

\section{Analisis ANP untuk Mencari Faktor Paling Berpengaruh}

Dalam metode ANP, langkah awal adalah menentukan struktur jaringan (Gambar 1), yang menunjukkan keterkaitan antar semua faktor. Dari hasil pengolahan berdasar ANP disusun ilustrasi matriks keterkaitan dalam faktor jaringan seperti disajikan pada Tabel 3.

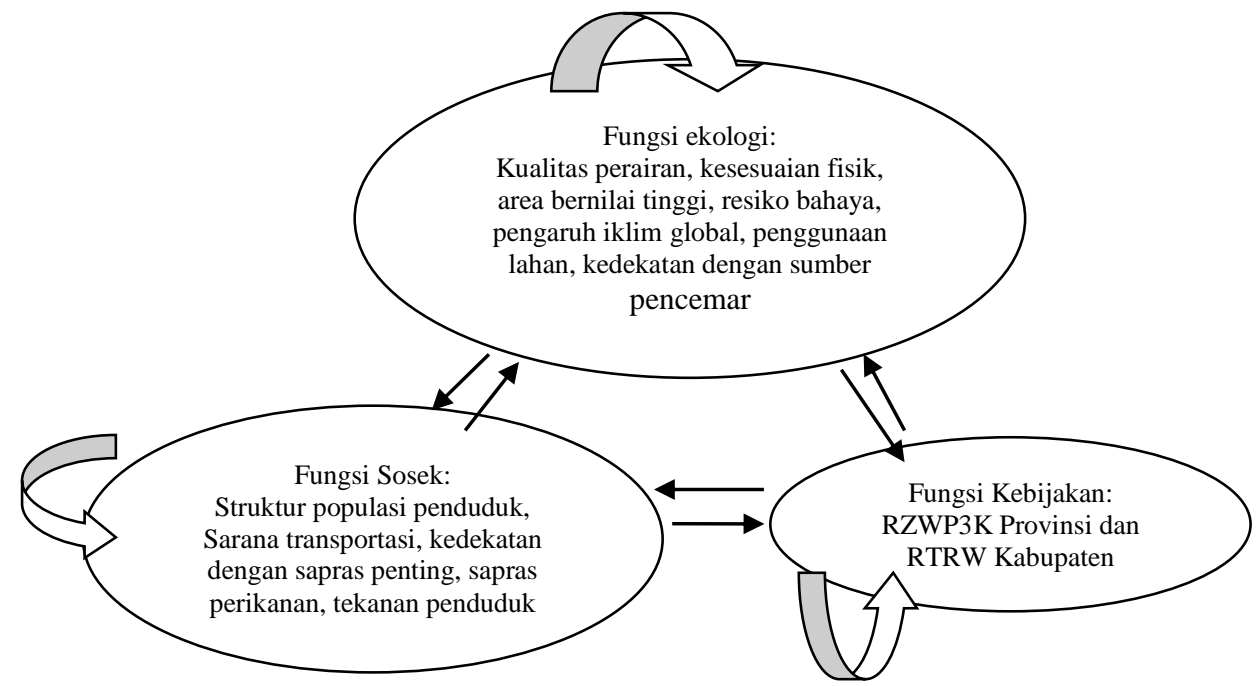

Gambar 1. Struktur jaringan kriteria pemanfaatan ruang

Tabel 3. Contoh matriks keterkaitan kriteria pada jaringan ANP

\begin{tabular}{|c|c|c|c|c|c|c|c|}
\hline \multirow[t]{2}{*}{ Kluster } & & \multicolumn{2}{|c|}{ Ekologi } & \multicolumn{2}{|c|}{ Sosek } & \multicolumn{2}{|c|}{ Kebijakan } \\
\hline & Faktor & $\mathrm{KF}$ & IG & Transportasi & Sapras & RTRW & RZWP3K \\
\hline \multirow{2}{*}{ Ekologi } & $\mathrm{KF}$ & 0 & ++ & ++++ & +++ & +++ & +++ \\
\hline & IG & ++ & 0 & ++++ & ++ & ++ & ++ \\
\hline \multirow{2}{*}{ Sosek } & Trans & + & 0 & 0 & +++ & +++ & +++ \\
\hline & Sapras & + & 0 & +++ & 0 & +++ & +++ \\
\hline \multirow{2}{*}{ Kebijakan } & RTRW & + & 0 & ++ & ++ & 0 & ++ \\
\hline & RZWP3K & + & 0 & ++ & ++ & ++ & 0 \\
\hline
\end{tabular}

Keterangan : $0=$ tidak memiliki bobot tingkat pengaruh 
Dalam perhitungan di ANP, nilai keterkaitan ini diberikan secara relatif, dimana jika dianggap semakin berpengaruh maka nilainya semakin besar misalnya 9 , dan jika pengaruhnya kecil maka diberi nilai 1 , atau tidak berpengaruh maka diberi nilai 0 . Dengan memasukkan nilai-nilai yang sudah ditetapkan ke dalam proses perhitungan, maka akhirnya diperoleh bobot berdasarkan kelompok yang sudah ditentukan. Dari hasil pengolahan data dalam ANP diperoleh nilai fungsi pemanfaatan ruang dengan fungsi kebijakan memiliki tingkat pengaruh paling tinggi 34.88 persen, menyusul pengaruh fungsi ekologi sebesar 33.99 persen dan fungsi sosial ekonomi sebesar 31.13 persen. Hal ini menunjukkan bahwa kriteria kebijakan menjadi penentu yang dominan dalam menentukan kebijakan dalam mengambil keputusan untuk pemanfaatan ruang di wilayah pesisir.
Hasil yang diperoleh dari ANP ini adalah limiting supermatrix yang selanjutnya dinormalisasi terhadap faktor masing-masing sehingga jumlah setiap kolom untuk setiap faktor adalah sama dengan satu. Tabel 4 merupakan matriks prioritas yang menunjukkan bobot dan peringkat faktor yang mempengaruhi pemanfaatan ruang, yang merupakan hasil kombinasi semua variabel. Berdasarkan kombinasi ini akan dihasilkan peta kesesuaian pemanfaatan ruang.

Tabel 4 menunjukkan bahwa dalam pemanfaatan ruang, faktor yang dominan pengaruhnya adalah kebijakan RZWP3K Provinsi (Rencana Zonasi Wilayah Pesisir dan Pulau-Pulau Kecil) dan RTRW Kabupaten serta yang paling rendah adalah pengaruh iklim global. Hal ini berarti RZWP3K Provinsi dan RTRW Kabupaten sangat berperan karena memiliki pengaruh yang sangat besar terhadap pemanfaatan ruang.

Tabel 4. Matriks prioritas pemanfaatan ruang

\begin{tabular}{clccc}
\hline No & \multicolumn{1}{c}{ Faktor Pemanfaatan Ruang } & $\begin{array}{c}\text { Prioritas } \\
\text { Inter kluster }\end{array}$ & $\begin{array}{c}\text { Prioritas Antar } \\
\text { kluster }\end{array}$ & Persen \\
\hline 1 & RZWP3K Provinsi Banten & 0.5009 & 0.1689 & 16.89 \\
2 & RTRW Kabupaten Pandeglang & 0.4991 & 0.1681 & 16.81 \\
3 & Sarana Transportasi & 0.2215 & 0.0667 & 6.67 \\
4 & Struktur populasi penduduk & 0.2160 & 0.0665 & 6.65 \\
5 & Sarana dan prasarana perikanan & 0.2047 & 0.0632 & 6.32 \\
6 & Penggunaan Lahan & 0.1710 & 0.0608 & 6.08 \\
7 & Kesesuaian fisik perairan & 0.1683 & 0.0605 & 6.05 \\
8 & Risiko bahaya & 0.1593 & 0.0580 & 5.80 \\
9 & Tekanan penduduk & 0.2039 & 0.0565 & 5.65 \\
10 & Area bernilai tinggi & 0.1449 & 0.0538 & 5.38 \\
11 & Kualitas perairan & 0.1336 & 0.0499 & 4.99 \\
12 & Kedekatan dengan sapras penting & 0.1539 & 0.0479 & 4.79 \\
13 & Kedekatan dengan sumber pencemar & 0.1158 & 0.0423 & 4.23 \\
14 & Pengaruh iklim global & 0.1071 & 0.0371 & 3.71 \\
\hline & Jumlah & 3.0000 & 1.0000 & 100.00 \\
\hline
\end{tabular}

\section{Analisis Kesesuaian dan Peta Arahan Pemanfaatan Ruang Pesisir}

Hasil analisis kesesuaian untuk pemanfaatan ruang menunjukkan wilayah daratan yang dimanfaatkan untuk 5 (lima) rencana pemanfaatan yang berbeda untuk wilayah darat $(32,695.9$ ha) dan wilayah laut $(63,459.5$ ha). Ditemukan perbedaan luasan yang sesuai untuk berbagai pemanfaatan di darat seperti disajikan pada
Tabel 5, dan kesesuaian pemanfaatan di laut seperti disajikan di Tabel 6. Mengingat variabel penentu untuk setiap kesesuaian pemanfaatan ada yang sama dan juga dapat berbeda, maka ada kemungkinan lokasi tertentu sesuai untuk berbagai peruntukan. Pada bagian berikut akan diuraikan kesesuaian peruntukan khususnya ditinjau dari parameter fisik.

Tabel 5. Luas kesesuaian lahan pemanfaatan ruang wilayah darat

\begin{tabular}{rlrrrrr}
\hline \multirow{2}{*}{ No } & \multirow{2}{*}{ Kelas } & \multicolumn{1}{c}{ Budidaya Laut } & \multicolumn{1}{c}{ Konservasi } & \multicolumn{1}{c}{ Pariwisata } & \multicolumn{1}{c}{ Pelabuhan } & \multicolumn{1}{c}{ Tangkap } \\
\cline { 3 - 6 } & & \multicolumn{1}{c}{ Luas, ha (\%) } & \multicolumn{1}{c}{ Luas, ha (\%) } & \multicolumn{1}{c}{ Luas, ha (\%) } & \multicolumn{1}{c}{ Luas, ha (\%) } & \multicolumn{1}{c}{ Luas, ha (\%) } \\
\hline 1 & Sesuai & $12,401.4(37.9)$ & $4,361.3(13.3)$ & $8,414.6(25.7)$ & $3,864.3(11.8)$ & $3,314.1(10.1)$ \\
2 & Kurang sesuai & $13,560.8(41.5)$ & $21,024.6(64.3)$ & $16,316.8(49.9)$ & $20,571.9(62.9)$ & $16,031.3(49.1)$ \\
3 & Tidak sesuai & $6,733.7(20.6)$ & $7,309.9(22.4)$ & $7,964.5(24.4)$ & $8,259.6(25.3)$ & $13,350.4(40.8)$ \\
\hline & Jumlah & $32,695.9(100.00)$ & 100 & 100 & 100 & 100 \\
\hline
\end{tabular}

Tabel 6. Luas kesesuaian lahan pemanfaatan ruang wilayah laut

\begin{tabular}{rlrrrrr}
\hline \multirow{2}{*}{ No } & \multirow{2}{*}{ Kelas } & \multicolumn{1}{c}{ Budidaya Laut } & \multicolumn{1}{c}{ Konservasi } & \multicolumn{1}{c}{ Pariwisata } & \multicolumn{1}{c}{ Pelabuhan } & \multicolumn{1}{c}{ Tangkap } \\
\cline { 3 - 6 } & & \multicolumn{1}{c}{ Luas, ha (\%) } & \multicolumn{1}{c}{ Luas, ha (\%) } & \multicolumn{1}{c}{ Luas, ha (\%) } & \multicolumn{1}{c}{ Luas, ha (\%) } & \multicolumn{1}{c}{ Luas, ha (\%) } \\
\hline 1 & Sesuai & $7,463.1(11.8)$ & $8,455.2(13.3)$ & $3,142.9(5.0)$ & $9,870.6(15.6)$ & $63,459.4(100.0)$ \\
2 & Kurang sesuai & $23,222.2(36.6)$ & $25,054.7(39.5)$ & $40,869.9(64.4)$ & $50,110.9(78.9)$ & 0.0 \\
3 & Tidak sesuai & $32,774.2(51.6)$ & $29,949.6(47.2)$ & $19,446.6(30.6)$ & $3,477.9(5.5)$ & 0.0 \\
\hline & Jumlah & $63,495.5(100)$ & 100 & 100 & 100 & 100 \\
\hline
\end{tabular}

Secara spasial, di wilayah darat daerah yang berkesesuaian paling luas adalah untuk budidaya laut, dengan luas sebesar 12,401.4 ha. Daerah yang termasuk dalam wilayah ini desa Cigorondong dan Panimbang jaya. 
Di wilayah laut, kesesuaian terbesar adalah untuk perairan tangkap $(63,495.4$ ha) sedangkan daerah yang sesuai untuk budidaya laut mempunyai luas 7,463.1 ha. Daerah yang sesuai untuk budidaya laut menyebar di perairan desa Caringin sampai Tanjung jaya. Faktor yang paling dominan dalam mempengaruhi kesesuaian di wilayah laut ini adalah kondisi substrat perairan berupa pasir dan pasir berlumpur dengan kedalaman perairan sekitar 8-10 meter. Kondisi tersebut layak untuk dijadikan sebagai lahan budidaya kerangan dan keramba jaring apung.

Kawasan pelabuhan perikanan saat ini sejalan dengan hasil analisis, yang terdapat di desa Panimbang jaya, Sidamukti dan desa Teluk Kecamatan Labuan. Di wilayah ini sarana prasarana perikanan tangkap sangat lengkap dengan bahaya abrasi yang kecil dan juga diperuntukkan untuk kawasan perkotaan. Untuk wilayah laut, faktor dan kriteria yang diprioritaskan untuk pelabuhan perikanan pantai adalah kedalaman perairan di atas 9 meter, substrat perairan lempung berpasir, tinggi gelombang kurang dari 1 meter dan kecepatan arus kurang dari $0.2 \mathrm{~m} \mathrm{~s}^{-1}$. Daerah yang (Oktavia, 2011) mempunyai kriteria perairan tersebut adalah kecamatan Labuan, perairan desa Sukarame dan sekitar pulau Liwungan kecamatan Panimbang.

Kawasan perikanan tangkap yang sesuai mempunyai luas lahan 3,314.1 ha. Daerah yang paling sesuai adalah desa Sidamukti dan Teluk. Wilayah perairan di Pandeglang, pada umumnya mempunyai kondisi fisik perairan yang relatif seragam dan seluruh perairan di Kabupaten Pandeglang sesuai untuk dijadikan zonasi perikanan tangkap. Faktor yang bisa dijadikan pembatas untuk meningkatkan produksi perikanan tangkap dan meminimalisir penangkapan yang merusak lingkungan adalah membatasi penggunaan alat tangkap yang tidak ramah lingkungan.
Luas lahan yang sesuai untuk kawasan konservasi 4,361.3 ha. Hasil analisis menunjukkan bahwa wilayah yang sesuai terletak di desa Tamanjaya dan Ujungjaya. Lahan dengan kelas sesuai untuk wilayah laut, 8,455.2 ha. Perairan yang mempunyai kategori sesuai untuk kondisi tersebut adalah sekitar perairan Taman jaya dan Pulau Badul. Kemudian untuk pengembangan daerah pariwisata, maka wilayah darat yang paling sesuai adalah Desa Caringin, Citeureup, Mekarsari, Panimbang jaya, Tanjung jaya dan Sukamaju. Sedangkan wilayah yang sesuai pariwisata perairan terdapat di daerah pulau kecil di kecamatan Sumur desa Kertajaya yang saat ini masih mempunyai tutupan karang di atas $75 \%$ wilayah dan baik untuk kegiatan menyelam dalam air untuk melihat keindahan laut.

\section{Sintesis Pemanfaatan Ruang Wilayah Pesisir}

Sintesis pemanfaatan ruang diperoleh dengan melihat kesesuaian dari semua faktor yang mempunyai bobot paling tinggi dalam setiap kesesuaian pemanfaatan ruang. Hasil penentuan zonasi adakalanya hanya menghasilkan satu pilihan pemanfaatan, tetapi kalau pilihan pemanfaatan lebih dari satu maka jika saling bersesuaian maka semuanya disampaikan sebagai zonasi yang ditawarkan, sedangkan jika ada pertentangan, maka akan dipilih satu alternatif terbaik sehingga tidak terjadi konflik.

Dominan keputusan penilaian pemanfaatan yang dihasilkan berasal dari penilaian satu terbaik dan menghasilkan satu pilihan zonasi, misalnya budidaya atau pariwisata, dan juga dihasilkan pilihan yang terdiri lebih dari satu pilihan zonasi, misalnya pariwisata, pelabuhan dan pelabuhan penangkapan. Kenampakan spasial hasil sintesis disajikan di Gambar 2.



Gambar 2. Peta arahan pemanfaatan ruang wilayah pesisir 


\section{SIMPULAN}

Dari hasil kajian ini dapat disimpulkan hal-hal sebagai berikut:

1. Permasalahan pengelolaan wilayah pesisir dan lautan di Kabupaten Pandeglang dikelompokkan atas 4 kategori: kerusakan bio-geofisik lingkungan pesisir, konflik pemanfaatan, kekosongan dan ketidak-pastian hukum, dan belum adanya perencanaan pengelolaan wilayah pesisir dan laut.

2. Faktor-faktor yang berpengaruh dalam pemanfaatan ruang pesisir secara berurutan dari paling besar ke yang terkecil adalah rencana zonasi wilayah pemanfaatan perikanan dan kelautan (RZWP3K) dan rencana tata ruang wilayah kabupaten (RTRWK), transportasi, struktur populasi, sarana-prasarana, penggunaan lahan, kesesuaian lahan dan risiko bahaya.

3. Hasil analisis kesesuaian lahan untuk lima jenis pemanfaatan ruang diperoleh bahwa lokasi pemanfaatan budidaya laut lebih sesuai di perairan Pagelaran sampai Panimbang. Pemanfaatan lahan konservasi perairan sesuai pada perairan Taman jaya sekitar Pulau Badul. Wilayah yang paling menunjang untuk dijadikan kawasan pariwisata bahari adalah perairan Sukaresmi sampai Tanjung Jaya dan kawasan pulau-pulau kecil di Ujung kulon. Kemudian Pelabuhan perikanan pantai lebih sesuai di desa Pejamben, Carigin, Cigondang dan desa Teluk.

4. Dihasilkan arahan pemanfaatan ruang pesisir dan laut kabupaten yang spesifik pada lokasi tertentu. Terdapat arahan zonasi yang bersifat tunggal yang dapat dipakai secara langsung, dan ada arahan lokasi yang dapat dimanfaatkan untuk beberapa pilihan. Zonasi tunggal yang diusulkan mendominasi usulan, dan masih ada beberapa lokasi diusulkan lebih dari satu zonasi. Untuk kedua bentuk usulan masih diperlukan penyesuaian jika diperlukan usulan pemanfaatan ruang lain.

\section{DAFTAR PUSTAKA}

Buyukyacizi, M. and S. Meral. 2003. The analytic hierarchy and analytical network processes. Journal of Mathematics and Statistics, 32:65-73.

Dahuri, R., J. Rais, S.P. Ginting, dan M.J. Sitepu. 2001. Pengelolaan Sumber Daya Wilayah Pesisir dan Lautan Secara Terpadu. PT. Padnya Paramita. Jakarta.

Dishidros. 2012. Peta Bathymetri No 71, skala 1:200,000. Jakarta, TNI-AL, RI.
Direktorat Jenderal KP3K Kementrian Kelautan dan Perikanan RI. 2011. Ketentuan Mengenai Penyusunan Rencana Zonasi wilayah Pesisir dan Pulau-pulau Kecil (RZWP3K) Kab/Kota. Direktorat Jenderal KP3K Kementrian Kelautan dan Perikanan RI. Jakarta.

Elly, M.J. 2006. Rencana pengembangan wisata bahari kawasan perairan teluk Lada, Banten dengan pendekatan sistem informasi geografis [Tesis]. IPB. Bogor.

Mulyawati, L.S. 2008. Prospek pengembangan kawasan wisata di Koridor Cilegon-Pandeglang Provinsi Banten [Tesis]. IPB. Bogor.

Oktavia, R., J.I. Parinowo, dan P. Manurung. 2011. Variasi muka laut dan arus geostrofik permukaan perairan selat sunda berdasarkan data pasut dan angin tahun 2008. Jurnal Ilmu dan Teknologi Kelautan Tropis, $3: 127-152$.

Pemda Kabupaten Pandeglang. 2011. Raperda Mengenai Rencana Tata Ruang Wilayah Kabupaten Kabupaten Pandeglang tahun 2011-2031. Pandeglang, Sekretariat Daerah Kabupaten Pandeglang.

Pourebrahim, M. Hadipor, and M. Mokhtar. 2010. Analytic network process for criteria selection in sustainable coastal land use planning. Journal Ocean and Coastal Management, 53:544-551.

Rumagia, F. 2008. Analisis Pemanfaatan ruang wilayah pesisir dalam pelaksanaan otonomi daerah di Kabupaten Buru, Maluku [Tesis]. IPB. Bogor.

Saaty, T.L. 2005. Theory and Applications of the Analytic Network Process: Decision Making with Benefits, Opportunities, Costs, and Risks. Pittsburgh, PA: RWS Publications.

Sekretariat Negara, 2007a. Undang-Undang No. 26 Tahun 2007 tentang Penataan Ruang, Lembaran Negara RI Tahun 2007, No.68. Sekretariat Negara, Jakarta.

Sekretariat Negara, 2007b. Undang-Undang No. 27 Tahun 2007 tentang Pengelolaan Pesisir dan Pulau-Pulau Kecil. Sekretariat Negara, Jakarta. 